\title{
STRUCTURE AND SOME BIOLOGICAL PROPERTIES OF Fe(III) COMPLEXES WITH NITROGEN-CONTAINING LIGANDS
}

\author{
Ion Bulhac ${ }^{a^{*}}$, Alexandra Deseatnic-Ciloci ${ }^{\mathrm{b}}$, Paulina Bourosh ${ }^{\mathrm{c}}$, Janetta Tiurina ${ }^{\mathrm{b}}$, Olga Bologa ${ }^{\mathrm{a}}$, \\ Cezara Bivol $^{\mathrm{b}}$, Steliana $\mathrm{Clapco}^{\mathrm{b}}$, Ana Verejan ${ }^{\mathrm{a}}$, Svetlana Labliuc ${ }^{\mathrm{b}}$, Olga Danilescu ${ }^{\mathrm{a}}$ \\ ${ }^{a}$ Institute of Chemistry of Academy of Sciences of Moldova, 3, Academiei str., Chisinau MD-2028, Republic of Moldova \\ ${ }^{b}$ Institute of Microbiology and Biotechnology of Academy of Sciences of Moldova, 1, Academiei str., \\ Chisinau MD-2028, Republic of Moldova \\ 'Institute of Applied Physics of Academy of Sciences of Moldova, 5, Academiei str., Chisinau MD-2028, Republic of Moldova \\ *e-mail:ionbulhac@yahoo.com
}

\begin{abstract}
Four coordination compounds of iron(III) with ligands based on hydrazine and sulfadiazine: $[\mathrm{Fe}(\mathrm{dig})] \mathrm{Cl}_{3} \cdot 2 \mathrm{H}_{2} \mathrm{O}$ (I) (dig-semicarbazide diacetic acid dihydrazide), [Fe(HL)SO $\left.\mathrm{SO}_{4}\right]$ (II) (HL - sulfadiazine), $\left[\mathrm{Fe}\left(\mathrm{H}_{2} \mathrm{~L}^{1}\right)\left(\mathrm{H}_{2} \mathrm{O}\right)_{2}\right]\left(\mathrm{NO}_{3}\right)_{3} \cdot 5 \mathrm{H}_{2} \mathrm{O} \quad(\mathrm{III}) \quad\left(\mathrm{H}_{2} \mathrm{~L}^{1}\right.$-2,6-diacetylpyridine bis(nicotinoylhydrazone) and $\left[\mathrm{Fe}\left(\mathrm{H}_{2}^{2} \mathrm{~L}^{2}\right)\left(\mathrm{H}_{2}^{2} \mathrm{O}\right)_{2}\right]\left(\mathrm{NO}_{3}\right)_{3} \cdot 1.5 \mathrm{H}_{2} \mathrm{O}(\mathbf{I V})\left(\mathrm{H}_{2} \mathrm{~L}^{2}-2,6\right.$-diacetylpyridine bis(isonicotinoylhydrazone) were synthesized. The spectroscopic and structure characterisation, as well as their biological properties, are presented. All tested coordination compounds, caused an inhibitory effect on the biosynthesis of hydrolases of the producer Aspergillus niger CNMN FD-10. The effect increased with the raise of the concentration from $5 \mathrm{mg} / \mathrm{L}$ to $15 \mathrm{mg} / \mathrm{L}$. The complexes largely inhibited cellobiohydrolase and less- $\beta$-glucosidase. The inhibitory effect of the coordination compounds was quite similar in the case of endoglucanase and xylanase. Compound $\mathbf{I}$, containing both chloride ions and dig, demonstrated a stronger inhibitory effect, while compound III, containing $\mathrm{NO}_{3}^{-}$ions, showed the weakest inhibitory action.
\end{abstract}

Keywords: iron complexes, nitrogen-containing ligands, structure, biological properties.

Received: October 2015/ Revised final: January 2016/ Accepted: February 2016

\section{Introduction}

In the modern microbiology, investigation of the effects of external factors on the physiology of microorganisms remains an actual issue. Such studies allow solving the practical problems and implementation of the new technologies in biology and medicine.

The literature, in the last decades, denotes high physiological activity of the coordination compounds of transition metals on biological objects, including microorganisms [1-13]. Some authors note a significant role of these compounds in the directed synthesis of biologically active substances from microalgae and cyanobacteria, filamentous fungi and yeast $[1-10,12]$.

Studies of the effects of coordination compounds on biosynthesis of extracellular hydrolases in filamentous fungi have been previously carried out [3-7,14]. It was established that these effects depend both on the properties of compounds (chemical composition, molecular structure, nature of the ligand and coordinated metal atom) and genus and species of the micromycetes strains, and specificity of the synthesized enzymes [3-7,14]. Some coordination compounds exhibit a selective action on the components of the synthesized enzyme complex. Thus, by adding the molybdenum complex with valine $-\mathrm{MoO}_{2}(\mathrm{acac})_{2}$ Val (acac=acetylacetone, Val=valine) into the nutrient medium, the biosynthesis of $\beta$-glucosidase in micromycete Penicillium expansum CNMN FD 5C - producer of cellulases was enhanced by $69.4 \%$, while the level of endoglucanase and cellobiohydrolase was not modified. Study of the influence of $\left(\mathrm{NH}_{4}\right)_{2} \mathrm{VO}_{2} \mathrm{Gly}$ $(\mathrm{Gly}=\mathrm{glycine})$ on biosynthesis of cellulases of the same strain showed that the dioxovanadium complex increased the activity of all components of cellulase complex by $17.6-40.3 \%$ [14].

The targeted application of the coordination compounds of $3 d$-elements as regulators of the microbial synthesis of bioactive substances requires accumulation of factual material on the nature of their influence on all phases of the development of microorganisms and also identification of optimal conditions for their use. All of this information will ensure the resolution of some theoretical issues, such as elucidation of the mechanism of action of coordination compounds, establishing the relationship between the composition, structure and enzyme activity of the microorganisms, as well as the development of methods for their practical use. These objectives can be achieved by expanding both, the diversity of microorganisms and the involved in researches complexes.

Iron is one of the essential microelements for microorganisms. It is involved in the respiration in microorganisms, being also necessary for the protein, carbohydrate and lipid metabolism, including protein synthesis. Iron is crucial structure component of the cytochromes, which catalyze the process of electron transfer in the mitochondria. In living organisms redox system $\mathrm{Fe}^{3+} / \mathrm{Fe}^{2+}$ plays an unique role $[15,16]$.

This study was aimed at investigation of the effect of iron(III) complexes with various organic ligands derived from hydrazine and sulfadiazine on the biosynthesis of cellulases and xylanases at Aspergillus niger CNMN FD 10 micromycete. 


\section{Materials and methods \\ Chemistry}

$[\mathrm{Fe}(\mathrm{dig})] \mathrm{Cl}_{3} \cdot 2 \mathrm{H}_{2} \mathrm{O}(\mathbf{I})$ was obtained by mixing the ethanolic solutions of $\mathrm{FeCl}_{3} \cdot 6 \mathrm{H}_{2} \mathrm{O}(1.0 \mathrm{~g}, 3.7 \mathrm{mmol}$ in $50 \mathrm{~mL}$ ethanol) and digsemi $(0.8 \mathrm{~g}, 3.7 \mathrm{mmol}$ in $40 \mathrm{~mL}$ ethanol). The formed dark brown residue was separated by filtration, washed with ethanol and diethyl ether. The complex is soluble in water, less soluble in alcohol and diethyl ether. Yield$75 \%[17,18]$.

$\left[\mathrm{Fe}(\mathrm{HL}) \mathrm{SO}_{4}\right]$ (II) was obtained by refluxing $\mathrm{FeSO}_{4} \cdot 7 \mathrm{H}_{2} \mathrm{O}(2.0 \mathrm{~g}, 0.72 \mathrm{mmol})$ and sulfadiazine $(0.22 \mathrm{~g}$, $0.88 \mathrm{mmol})$ in methanol $(20 \mathrm{~mL})$ for 2 hours in a water bath. The brown precipitate was separated from the mother liquor by filtration, washed with methanol and diethyl ether. The complex is well soluble in methanol and DMF, less soluble in water and diethyl ether. Yield- $80 \%$ [13].

Methods for the synthesis of coordination compounds of iron with semicarbazide diacetic acid dihydrazide, sulfadiazine, 2,6-diacetylpyridine bis(nicotinoylhydrazone) and 2,6-diacetylpyridine bis(isonicotinoylhydrazone) have been developed. The complexes of iron(III) with Schiff bases on the basis of 2,6-diacetylpyridine were obtained in two ways: by condensation reactions of 2,6-diacetylpyridine with hydrazides of nicotinic and isonicotinic acid on the matrix of iron ions and by direct interaction of iron salt with the corresponding Schiff bases.

For determining the composition, spectral characteristics, molecular and crystal structures of the complexes elemental analysis, IR and Mössbauer spectroscopy and single crystal X-ray diffraction were applied. The composition and structure of the complexes III and IV were established by IR spectroscopy and X-ray diffraction and can be described by the following formulas: $\left[\mathrm{Fe}\left(\mathrm{H}_{2} \mathrm{~L}^{1}\right)\left(\mathrm{H}_{2} \mathrm{O}\right)_{2}\right]\left(\mathrm{NO}_{3}\right)_{3} \cdot 5 \mathrm{H}_{2} \mathrm{O}(\mathrm{III})$ and $\left[\mathrm{Fe}\left(\mathrm{H}_{2} \mathrm{~L}^{2}\right)\left(\mathrm{H}_{2} \mathrm{O}\right)_{2}\right]\left(\mathrm{NO}_{3}\right)_{3} \cdot 1.5 \mathrm{H}_{2} \mathrm{O}(\mathbf{I V})$.

\section{IR spectroscopy}

The IR spectra of the ligands and complexes were recorded on spectrophotometer FT-IR Perkin-Elmer "Spectrum 100" in the vaseline oil in the region 4000-400 $\mathrm{cm}^{-1}$ and ATR in the region 4000-650 $\mathrm{cm}^{-1}$, and the absorption bands has been attributed according to the reference literature [23-26], (s. - strong, v.s. - very strong, m. - middle, w. weak, sh. - shoulder, br. - broad).

\section{Mössbauer spectroscopy}

The ${ }^{57} \mathrm{Fe}-\mathrm{Mössbauer}$ spectra were recorded with a common spectrometer in the constant-acceleration mode (MS4, Edina, USA) equipped with a ${ }^{57}$ Co source in a rhodium matrix.

\section{$X$-ray Crystallography}

The unit cell parameters and the sets of reflections intensity were measured at $293 \mathrm{~K}$ on a Xcalibur E CCD diffractometer for crystals III and IV (MoK radiation, graphite monochromator). The structures of compounds III and IV were solved by the direct methods and refined by least squares in the anisotropic full matrix approximation for nonhydrogen atoms (SHELX-97) [19]. The C, N, and O-bound $\mathrm{H}$ atoms were placed in calculated positions and were treated

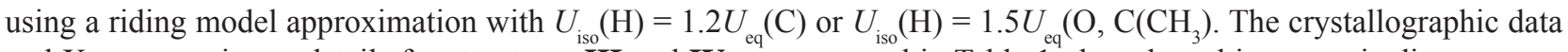
and X-ray experiment details for structures III and IV are presented in Table 1, the selected interatomic distances are listed in Table 2 and the geometric parameters of hydrogen bonds are given in Table 3. Crystallographic data for III and IV have been deposited with the Cambridge Crystallographic Data Center, CCDC 1429807, 1429808. Copies of this information may be obtained from The Director, CCDC, 12 Union Road, Cambridge, CB2 1EZ, UK (fax: +44-1233336033; e-mail: deposit@ccdc.cam.ac.uk or www: http://www.ccdc.cam.ac.uk).

Table 1

Crystal data and structure refinement data for III and IV.

\begin{tabular}{lll}
\hline Parameter & Compound III & Compound IV \\
\hline Formula & $C_{21} H_{33} F e N_{10} O_{18}$ & $C_{21} H_{25} F e N_{10} O_{14.50}$ \\
$M$ & 769.42 & 705.36 \\
Crystal system & monoclinic & monoclinic \\
Space group & $P 2_{1} / n$ & $\mathrm{P} 2 / c$ \\
$a, \AA$ & $13.0459(5)$ & $13.4325(6)$ \\
$b, \AA$ & $16.6677(4)$ & $15.0766(5)$ \\
$c, \AA$ & $15.2842(5)$ & $15.3908(8)$ \\
$\beta, 0$ & $100.730(3)^{\circ}$ & $107.895(5)$ \\
$V, \AA^{3}$ & $3265.38(17)$ & $2966.1(2)$ \\
$Z$ & 4 & 4 \\
$\rho_{\text {calc }}, \mathrm{g} / \mathrm{cm}^{3}$ & 1.565 & 1.580 \\
$\mu$, mm & 0.555 & 0.595 \\
$F(000)$ & 1596 & 1452 \\
Crystal size, mm & $0.35 \times 0.2 \times 0.1$ & $0.2 \times 0.15 \times 0.15$ \\
$\theta$ range for data collection, ${ }^{-1}$ & $2.91-25.50$ & $3.04-25.50$ \\
Index ranges & $-11 \leq h \leq 15$ & $-12 \leq h \leq 16$ \\
& $-19 \leq k \leq 11$ & $-16 \leq k \leq 18$ \\
& $-18 \leq l \leq 11$ & $-18 \leq l \leq 18$ \\
\hline
\end{tabular}




\begin{tabular}{lll}
\hline Parameter & Compound III & Compound IV \\
\hline Reflections collected/ & $10714 / 6047[\mathrm{R}(\mathrm{int})=0.0294]$ & $10286 / 5472[\mathrm{R}(\mathrm{int})=0.0476]$ \\
Independent reflections & 6047 & \\
Reflections with $I>2 \sigma(I)$ & 451 & 5472 \\
Parameters & 0.998 & 1.003 \\
$G O O F$ & $R_{1}=0.0544$ & $R_{1}=0.0631$, \\
Final $R$ indices $(I>2 \sigma(I))$ & $w R_{2}=0.1221$ & $w R_{2}=0.1415$ \\
& $R_{1}=0.1117$ & $R_{1}=0.1083$, \\
$R$ indices (all data) & $w R_{2}=0.1453$ & $w R_{2}=0.1628$ \\
& $0.553,-0.328$ & $0.558,-0.370$ \\
$\Delta \rho_{\max }, \Delta \rho_{\min }, e \times \AA^{-3}$ & &
\end{tabular}

Table 2

Bond lengths ( $\AA$ ) in coordination polihedra of III and IV.

\begin{tabular}{lcc}
\hline Bond & Compound III & Compound IV \\
\hline $\mathrm{Fe}(1)-\mathrm{O}(1)$ & $2.033(2)$ & $2.087(3)$ \\
$\mathrm{Fe}(1)-\mathrm{O}(2)$ & $2.029(2)$ & $2.043(3)$ \\
$\mathrm{Fe}(1)-\mathrm{O}(1 \mathrm{~W})$ & $2.036(2)$ & $2.035(3)$ \\
$\mathrm{Fe}(1)-\mathrm{O}(2 \mathrm{~W})$ & $2.035(2)$ & $2.028(3)$ \\
$\mathrm{Fe}(1)-\mathrm{N}(3)$ & $2.194(3)$ & $2.176(3)$ \\
$\mathrm{Fe}(1)-\mathrm{N}(4)$ & $2.188(3)$ & $2.203(3)$ \\
$\mathrm{Fe}(1)-\mathrm{N}(5)$ & $2.194(3)$ & $2.187(3)$ \\
\hline
\end{tabular}

Table 3

Geometric parameters of hydrogen bonds for III and IV ( $\AA$ and $\left.{ }^{\circ}\right)$.

\begin{tabular}{|c|c|c|c|c|c|}
\hline \multirow{2}{*}{$D-H \cdots A$} & \multicolumn{3}{|c|}{$d, \mathscr{A}$} & \multirow{2}{*}{$\angle D H A,^{\circ}$} & \multirow{2}{*}{$\begin{array}{l}\text { Symmetry transformations usea } \\
\text { to generate equivalent atoms }\end{array}$} \\
\hline & $D-H$ & $H \cdots A$ & $D \cdots A$ & & \\
\hline \multicolumn{6}{|c|}{ Compound III } \\
\hline $\mathrm{O}(1 \mathrm{~W})-\mathrm{H}(1 \mathrm{~W} 1) \cdots \mathrm{O}(6 \mathrm{~A})$ & 0.80 & 1.91 & $2.701(4)$ & 173 & $x, y, z$ \\
\hline $\mathrm{O}(1 \mathrm{~W})-\mathrm{H}(2 \mathrm{~W} 1) \cdots \mathrm{O}(3 \mathrm{~W})$ & 0.83 & 1.85 & $2.679(3)$ & 179 & \multirow{2}{*}{$\begin{array}{l}-x+1 / 2, y-1 / 2,-z+3 / 2 \\
-x+3 / 2, y+1 / 2,-z+3 / 2\end{array}$} \\
\hline $\mathrm{O}(2 \mathrm{~W})-\mathrm{H}(1 \mathrm{~W} 2) \cdots \mathrm{O}(7 \mathrm{~W})$ & 0.82 & 1.77 & $2.580(4)$ & 169 & \\
\hline $\mathrm{O}(2 \mathrm{~W})-\mathrm{H}(2 \mathrm{~W} 2) \cdots \mathrm{O}(9 \mathrm{~A})$ & 0.80 & 1.91 & $2.699(4)$ & 170 & $x, y, z$ \\
\hline $\mathrm{N}(1)-\mathrm{H}(1 \mathrm{~A}) \cdots \mathrm{O}(6 \mathrm{~W})$ & 0.86 & 1.87 & $2.715(4)$ & 170 & $x, y, z$ \\
\hline $\mathrm{N}(7)-\mathrm{H}(7 \mathrm{~A}) \cdots \mathrm{O}(1 \mathrm{~A})$ & 0.86 & 1.85 & $2.713(4)$ & 177 & $x, y, z$ \\
\hline $\mathrm{N}(7)-\mathrm{H}(7 \mathrm{~A}) \cdots \mathrm{O}(2 \mathrm{~A})$ & 0.86 & 2.60 & $3.200(5)$ & 128 & $x, y, z$ \\
\hline $\mathrm{O}(3 \mathrm{~W})-\mathrm{H}(1 \mathrm{~W} 3) \cdots \mathrm{O}(4 \mathrm{~A})$ & 0.84 & 1.93 & $2.769(4)$ & 173 & $x, y, z$ \\
\hline $\mathrm{O}(3 \mathrm{~W})-\mathrm{H}(2 \mathrm{~W} 3) \cdots \mathrm{O}(5 \mathrm{~W})$ & 0.84 & 1.91 & $2.726(4)$ & 162 & \multirow{2}{*}{$\begin{array}{l}x, y, z \\
-x+1,-y+1,-z+1\end{array}$} \\
\hline $\mathrm{O}(4 \mathrm{~W})-\mathrm{H}(1 \mathrm{~W} 4) \cdots \mathrm{O}(3 \mathrm{~W})$ & 0.86 & 2.55 & $2.959(4)$ & 110 & \\
\hline $\mathrm{O}(4 \mathrm{~W})-\mathrm{H}(2 \mathrm{~W} 4) \cdots \mathrm{O}(9 \mathrm{~A})$ & 0.84 & 2.04 & $2.855(4)$ & 163 & \multirow{2}{*}{$\begin{array}{l}x, y, z \\
-x+1,-y+1,-z+1\end{array}$} \\
\hline $\mathrm{O}(5 \mathrm{~W})-\mathrm{H}(1 \mathrm{~W} 5) \cdots \mathrm{O}(8 \mathrm{~A})$ & 0.84 & 2.25 & $2.962(4)$ & 143 & \\
\hline $\mathrm{O}(5 \mathrm{~W})-\mathrm{H}(1 \mathrm{~W} 5) \cdots \mathrm{O}(9 \mathrm{~A})$ & 0.84 & 2.31 & $3.102(5)$ & 158 & $-x+1,-y+1,-z+1$ \\
\hline $\mathrm{O}(5 \mathrm{~W})-\mathrm{H}(2 \mathrm{~W} 5) \cdots \mathrm{O}(1 \mathrm{~A})$ & 0.85 & 1.93 & $2.777(4)$ & 174 & $x, y+1, z$ \\
\hline $\mathrm{O}(6 \mathrm{~W})-\mathrm{H}(1 \mathrm{~W} 6) \cdots \mathrm{O}(3 \mathrm{~A})$ & 0.83 & 2.24 & $2.968(5)$ & 147 & $x, y, z$ \\
\hline $\mathrm{O}(6 \mathrm{~W})-\mathrm{H}(1 \mathrm{~W} 6) \cdots \mathrm{O}(2 \mathrm{~A})$ & 0.83 & 2.26 & $3.033(5)$ & 156 & \multirow{2}{*}{$\begin{array}{l}x, y, z \\
-x+3 / 2, y-1 / 2,-z+3 / 2\end{array}$} \\
\hline $\mathrm{O}(6 \mathrm{~W})-\mathrm{H}(2 \mathrm{~W} 6) \cdots \mathrm{O}(4 \mathrm{~W})$ & 0.80 & 2.03 & $2.737(4)$ & 147 & \\
\hline $\mathrm{O}(7 \mathrm{~W})-\mathrm{H}(1 \mathrm{~W} 7) \cdots \mathrm{O}(6 \mathrm{~W})$ & 0.80 & 2.26 & $3.054(5)$ & 168 & $x, y, z$ \\
\hline $\mathrm{O}(7 \mathrm{~W})-\mathrm{H}(2 \mathrm{~W} 7) \cdots \mathrm{O}(8 \mathrm{~A})$ & 0.85 & 2.20 & $3.013(5)$ & 160 & $x, y, z$ \\
\hline $\mathrm{O}(7 \mathrm{~W})-\mathrm{H}(2 \mathrm{~W} 7) \cdots \mathrm{O}(7 \mathrm{~A})$ & 0.85 & 2.27 & $2.952(5)$ & 138 & $x, y, z$ \\
\hline \multicolumn{6}{|c|}{ Compound IV } \\
\hline $\mathrm{O}(1 \mathrm{~W})-\mathrm{H}(1 \mathrm{~W} 1) \cdots \mathrm{O}(3 \mathrm{~W})$ & 1.02 & 1.68 & $2.568(9)$ & 143 & $x, y, z$ \\
\hline $\mathrm{O}(1 \mathrm{~W})-\mathrm{H}(1 \mathrm{~W} 1) \cdots \mathrm{O}(4 \mathrm{~W})$ & 1.02 & 1.73 & $2.649(11)$ & 148 & $x, y, z$ \\
\hline $\mathrm{O}(1 \mathrm{~W})-\mathrm{H}(2 \mathrm{~W} 1) \cdots \mathrm{O}(1 \mathrm{~A})$ & 0.93 & 1.76 & $2.683(4)$ & 172 & $x, y, z$ \\
\hline
\end{tabular}


Continuation of Table 3

\begin{tabular}{|c|c|c|c|c|c|}
\hline \multirow[t]{2}{*}{$D-H \cdots A$} & \multicolumn{3}{|c|}{$d, \AA$} & \multirow[t]{2}{*}{$\angle D H A,^{\circ}$} & \multirow{2}{*}{$\begin{array}{l}\text { Symmetry transformations used } \\
\text { to generate equivalent atoms }\end{array}$} \\
\hline & $D-H$ & $H \cdots A$ & $D \cdots A$ & & \\
\hline \multicolumn{6}{|c|}{ Compound IV } \\
\hline $\mathrm{O}(2 \mathrm{~W})-\mathrm{H}(1 \mathrm{~W} 2) \cdots \mathrm{O}(3 \mathrm{~A})$ & 0.89 & 1.82 & $2.669(4)$ & 159 & $x,-y+1 / 2, z+1 / 2$ \\
\hline $\mathrm{O}(2 \mathrm{~W})-\mathrm{H}(1 \mathrm{~W} 2) \cdots \mathrm{O}(2 \mathrm{~A})$ & 0.89 & 2.63 & $3.338(5)$ & 138 & $x,-y+1 / 2, z+1 / 2$ \\
\hline $\mathrm{O}(2 \mathrm{~W})-\mathrm{H}(2 \mathrm{~W} 2) \cdots \mathrm{O}(1)$ & 0.94 & 1.84 & $2.769(4)$ & 171 & $-x,-y,-z+2$ \\
\hline $\mathrm{N}(1)-\mathrm{H}(1 \mathrm{~A}) \cdots \mathrm{O}(5 \mathrm{~A})$ & 0.86 & 1.91 & $2.759(5)$ & 171 & $x, y, z$ \\
\hline $\mathrm{N}(7)-\mathrm{H}(7 \mathrm{~A}) \cdots \mathrm{O}(9 \mathrm{~A})$ & 0.86 & 1.97 & $2.805(6)$ & 162 & $x, y, z$ \\
\hline $\mathrm{N}(7)-\mathrm{H}(7 \mathrm{~A}) \cdots \mathrm{O}(8 \mathrm{~A})$ & 0.86 & 2.27 & $2.994(7)$ & 142 & $x, y, z$ \\
\hline
\end{tabular}

\section{Microbiology}

The effects of the synthesized coordination compounds on the biosynthesis of cellulases (cellobiohydrolase, endoglucanase, $\beta$-glucosidase) and xylanases at Aspergillus niger CNMN FD 10 micromycete have been investigated [20]. The method of submerged cultivation was applied. The producer was cultivated on the nutrient medium with the chosen composition $(\mathrm{g} / \mathrm{L})$ : beet pulp - 20.0, $\mathrm{KH}_{2} \mathrm{PO}_{4}-1.0, \mathrm{CaCl}_{2} \cdot 2 \mathrm{H}_{2} \mathrm{O}-0.1, \mathrm{KCl}-0.1, \mathrm{MgSO}_{4} \cdot 7 \mathrm{H}_{2} \mathrm{O}-0.3, \mathrm{NaNO}_{3}-$ $2.5, \mathrm{FeCl}_{3}-0.01, \mathrm{H}_{2} \mathrm{O}-1.0, \mathrm{pH} 5.5-6.0$, at $28-30^{\circ} \mathrm{C}$ under constant stirring on shaker at $180-220 \mathrm{rpm}$. The duration of the cultivation was 6-9 days; during this period a maximum of biosynthesis of the aforementioned enzymes is observed. The complexes were added to nutrient medium in the concentrations of 5,10 and $15 \mathrm{mg} / \mathrm{L}$. The samples without the coordination compounds served as control.

\section{Results and discussion Chemistry}

In compound I dig behaves like tridentate tripodal ligand. In the IR spectrum the complex absorption bands corresponding to stretching vibrations of $\mathrm{NH}$ and $\mathrm{NH}_{2}$ groups are found in the region $3050-3500 \mathrm{~cm}^{-1}$. However, the band of stretching vibrations of the bonds of amino group $\mathrm{NH}$ in the complex spectrum is shifted to longer wavelength region with $\approx 100 \mathrm{~cm}^{-1}$, as compared with its position in the spectrum of the free dihydrazide, indicating on the presence of $\mathrm{Me} \leftarrow \mathrm{NH}_{2}$ bond [21]. For dig, three bands are in the range of 1600-1700 $\mathrm{cm}^{-1}\left(1695,1670\right.$ and $\left.1635 \mathrm{~cm}^{-1}\right)$. Due to complexation, these bands are displaced by $30-50 \mathrm{~cm}^{-1}$ in the low frequency region, forming two strips (one wider), which suggests that the oxygen atoms of the carboxyl group are coordinated to the central atom [22].

The recorded at 300 and $80 \mathrm{~K}$ Mössbauer spectra of $[\mathrm{Fe}(\mathrm{dig})] \mathrm{Cl}_{3} \cdot 2 \mathrm{H}_{2} \mathrm{O}$ (I) have been studied. They show a symmetrical doublet with the following parameters: at $300 \mathrm{~K}$ IS $=0.69 \mathrm{~mm} / \mathrm{s}$ and QS $=1.37 \mathrm{~mm} / \mathrm{s}$; at $80 \mathrm{~K}$ IS $=0.79 \mathrm{~mm} / \mathrm{s}$ and $\mathrm{QS}=1.39 \mathrm{~mm} / \mathrm{s}$. The experimental value of the effective magnetic moment is equal to $6.04 \mathrm{MB}$ (the pure spin value $\mu_{\text {eff }}$ for 5 unpaired electron is equal to $5.92 \mathrm{MB}$ ). The values of Mössbauer spectrum and $\mu_{\text {eff }}$ correspond to the metal oxidation state +3 , i.e. iron is in the high-spin state. According to the value of the isomer shift and quadrupole splitting, the coordination environment of the central ion is nearly spherical, being completed by the donors of the organic ligand $(\mathrm{O}, \mathrm{NH}, \mathrm{N})$ and two water molecules. The molar conductivity of the aqueous solution of the complex is $391.8 \mathrm{ohm}^{-1} \cdot \mathrm{cm}^{2} \cdot \mathrm{mol}^{-1}$, which corresponds to four ions $[17,18]$.

The IR spectrum of $\left[\mathrm{Fe}(\mathrm{HL}) \mathrm{SO}_{4}\right]$ (II) contains typical bands for the sulfadiazine: $3400-3200\left(\mathrm{NH}^{2}\right.$ and $\mathrm{NH}_{2}$ groups), 1600-1500 $\mathrm{cm}^{-1}$ (aromatic ring), 1320-1160 $\mathrm{cm}^{-1}$ ( $\mathrm{SO}_{2}$ group) [13].

$\left[\mathrm{Fe}\left(\mathrm{H}_{2} \mathrm{~L}^{1}\right)\left(\mathrm{H}_{2} \mathrm{O}\right)_{2}\right]\left(\mathrm{NO}_{3}\right)_{3} \cdot 5 \mathrm{H}_{2} \mathrm{O}$ (III), IR, v(cm $\left.{ }^{-1}\right)$ : 3381 m., br., 3193 m., br., 3124 sh., 3085 m., 3063 m., 2988 m., br., 2750 m., br., 2650 m.,br., 2420 w., br., 2350 w.,br., 2106 w., 2006 w., 1752 w., 1737 w., 1630 m., 1617 sh., 1598 w., 1566 m., 1533 s., 1507 m., 1395 v.s., 1380 v.s., 1357 v.s., 1313 v.s., 1272 sh., 1212 sh., 1165 s., 1148 m., 1108 m., 1075 w., 1056 s., 1039 s., 1020 m., 997 m., 978 sh., 958 w., 920 m., 885 w., 874 w., 820 s., 773 w., 752 w., 731 s., 702 m., 689 w., 689 m., 664 w., 621 m., 565 m., 554 sh., 533 s., 495 w., 445 s.

The IR spectrum of complex III at $3600-1900 \mathrm{~cm}^{-1}$ is almost identical with the spectrum of compound IV. The high-intensity band corresponding to $v(\mathrm{C}=\mathrm{O})$, which in the spectrum of the non-coordinated ligand $\mathrm{H}_{2} \mathrm{~L}^{1}$ appears at $1663 \mathrm{~cm}^{-1}$, shifts to $1637 \mathrm{~cm}^{-1}$ in the spectrum of complex III, which proves that this group participates in the coordination to the metal atom. The absorption band at $1617 \mathrm{~cm}^{-1}$ can be assigned to the $v(\mathrm{CN})$ heterocycle, the bands at 1598,1533 and $752 \mathrm{~cm}^{-1}$ - to the pyridine ring vibrations, and the band at $1566 \mathrm{~cm}^{-1}$ - to $\delta(\mathrm{NH})$ hydrazide fragment. The absorption bands associated with the $\mathrm{NO}_{3}{ }^{-}$anions vibrations, with different functions, could be observed at 1507 , 1313 (the most intense band in the spectrum), 1300, 1039 and $997 \mathrm{~cm}^{-1}$. The fact that the main bands (1313 and $1300 \mathrm{~cm}^{-1}$ ), associated with fluctuations of $\mathrm{NO}_{3}^{-}$anions vibrations of the complex, shift to shorter wavelengths, as compared to those for free $\mathrm{NO}_{3}^{-}$anions (1380-1350 $\left.\mathrm{cm}^{-1}\right)$, demonstrated that these anions are involved in the formation of various hydrogen bonds in the complex, which correspond by value of this frequencies to the monocoordinated and chelate-bidentate $\mathrm{NO}_{3}{ }_{3}^{-}$ions $[23,26]$. The band corresponding to $\mathrm{v}(\mathrm{N}-\mathrm{N})$ appears at $1165 \mathrm{~cm}^{-1}$. The deformation vibrations $\delta(\mathrm{C}-\mathrm{H})$ of the aromatic rings were found: planar vibrations at 1148,1108 and $1020 \mathrm{~cm}^{-1}$; non-planar vibrations at 
$752 \mathrm{~cm}^{-1}$ (three adjacent hydrogen atoms) and $820 \mathrm{~cm}^{-1}$ (isolated hydrogen atom) [23-25]. The stretching vibrations Fe-N are located at 688 and $678 \mathrm{~cm}^{-1}$, and $\mathrm{Fe}-\mathrm{O}$ - at 495 and $445 \mathrm{~cm}^{-1}$.

$\left[\mathrm{Fe}\left(\mathrm{H}_{2} \mathrm{~L}^{2}\right)\left(\mathrm{H}_{2} \mathrm{O}\right)_{2}\right]\left(\mathrm{NO}_{3}\right)_{3} \cdot 1.5 \mathrm{H}_{2} \mathrm{O}(\mathbf{I V}), \mathrm{IR}, \mathrm{v}\left(\mathrm{cm}^{-1}\right): 3522$ m., br., 3151 w., 3117 w., 3080 m., 2990 m., br., 2894 m., br., 2793 m., br., 2762 m., br., 2652 m., br., 2581 m., br., 2452 m., br., 2342 sh., 1744 w., 1637 s., 1612 m., 1584 w., 1567 m., 1548 m., 1535 sh., 1498 m., 1409 s., 1379 sh., 1365 s., 1345 s., 1306 v.s., 1291 v.s., 1273 s., 1207 m., 1186 m., 1170 m., 1161 s., 1094 m., 1080 m., 1059 m., 1050 m., 1043 m., 1034 m., 1019 w., 1004 sh., 996 m., 913 m., 843 s., 827 s., 754 s., 722 w., 713 w., 691 m., 684 s., 651 w., 569 w., 556 w., 534 w., 500 w., 487 w., 442 m.

The IR spectrum is characterized by broad absorption in the range of $3500-1900 \mathrm{~cm}^{-1}$, the absorption bands of 3151 and $3117 \mathrm{~cm}^{-1}$ being distinguished on its background. These bands can be attributed to the stretching vibrations associated to $\mathrm{OH}$ and $\mathrm{NH}$-groups, respectively. The intense band at $1637 \mathrm{~cm}^{-1}$ can be referred to a coordinated $\mathrm{C}=\mathrm{O}$ group. The band of medium intensity at $1612 \mathrm{~cm}^{-1}$ can be assigned to the $v(\mathrm{CN})$ of the pyridine heterocycle and absorption bands at 1584,1534 and $754 \mathrm{~cm}^{-1}-$ to the heterocycle vibrations itself. The deformation vibrations $\delta(\mathrm{NH})$ were found at $1567 \mathrm{~cm}^{-1}$. The intense absorption band at $1409 \mathrm{~cm}^{-1}$ can be regarded as the result of interaction of $v(C=N)$ and $v(C=C)$ vibrations [23-25].

The most intense absorption bands of the spectrum are associated with the vibrations of $\mathrm{NO}_{3}^{-}$anion, which exerts various functions in the crystal lattice of the complex: 1498, 1306, 1291, 1043 and $996 \mathrm{~cm}^{-1}$. Shift of the most intense absorption band of $\mathrm{NO}_{3}^{-}\left(1291 \mathrm{~cm}^{-1}\right)$ to higher frequencies, in comparison with that of the free $\mathrm{NO}_{3}^{-}$anions $(1380-$ $1350 \mathrm{~cm}^{-1}$ ), proves that these anions are involved in the formation of various hydrogen bonds in the complex and by the value is close to the frequency of mono coordinated and chelate-bidentate $\mathrm{NO}_{3}{ }^{-}$anions [23-26]. The intense band at $1161 \mathrm{~cm}^{-1}$ refers to $v(\mathrm{~N}-\mathrm{N})$. The planar C-H deformation vibrations appear through the $1207,1050 \mathrm{~cm}^{-1}(1,4-\mathrm{substituted}$ aromatic ring) and 1171,1080 and $1034 \mathrm{~cm}^{-1}$ (1,2,3-substituted aromatic ring) absorption bands. Non-planar C-H deformation vibrations of the aromatic rings appear at $827 \mathrm{~cm}^{-1}$ (for two adjacent hydrogen atoms) and $754 \mathrm{~cm}^{-1}$ (for three adjacent hydrogen atoms) [24,25]. The $v(\mathrm{Fe}-\mathrm{N})$ oscillations are identified by bands at 692 and $685 \mathrm{~cm}^{-1}$ and $v(\mathrm{Fe}-\mathrm{O})$ - by bands at 487 and $442 \mathrm{~cm}^{-1}$, correspondingly.

The crystal and molecular structures of compounds III and IV were obtained by X-ray diffraction. It was established, that their crystals consists of complex mononuclear cations $\left[\mathrm{Fe}\left(\mathrm{H}_{2} \mathrm{~L}^{1}\right)\left(\mathrm{H}_{2} \mathrm{O}\right)_{2}\right]^{3+}$ and $\left[\mathrm{Fe}\left(\mathrm{H}_{2} \mathrm{~L}^{2}\right)\left(\mathrm{H}_{2} \mathrm{O}\right)_{2}\right]^{3+}$, $\mathrm{NO}_{3}{ }^{-}$anions and solvated water molecules. The polyhedral coordination of $\mathrm{Fe}(\mathrm{III})$ consists of pentagonal bipyramids formed by $\mathrm{N}_{3} \mathrm{O}_{2}$ donor atoms set of pentadentate neutral ligands $\mathrm{H}_{2} \mathrm{~L}^{1} / \mathrm{H}_{2} \mathrm{~L}^{2}$ and two oxygen atoms of the coordinated $\mathrm{H}_{2} \mathrm{O}$ molecules (Figures 1 and 2).

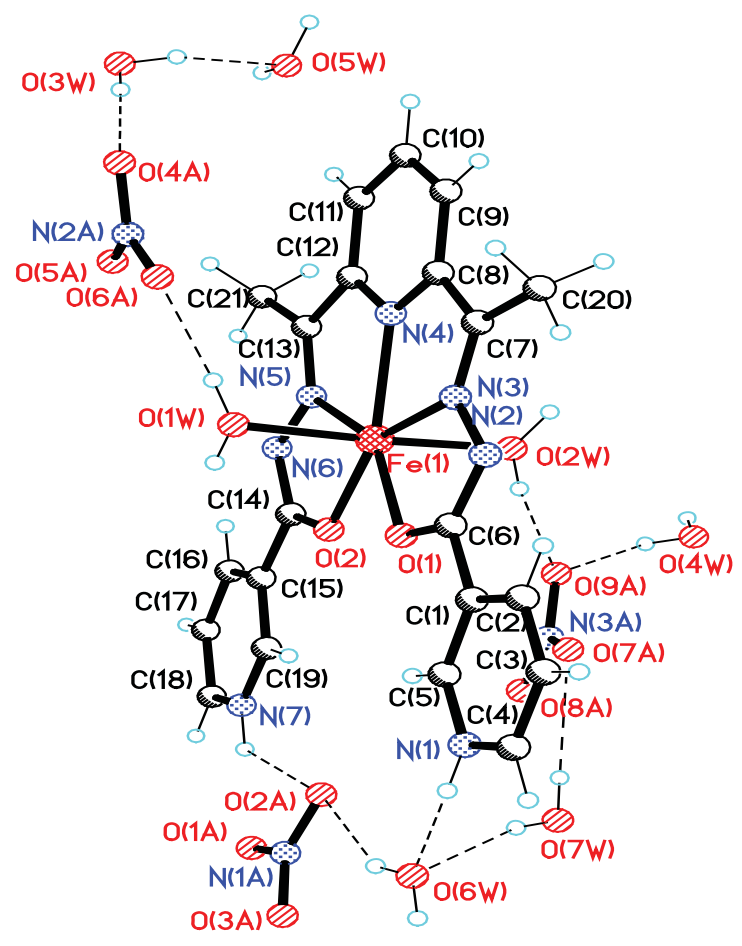

Figure 1. View of formula unit of III with numbering scheme.

The interatomic distances metal-ligand $\left(\mathrm{H}_{2} \mathrm{~L}^{1} / \mathrm{H}_{2} \mathrm{~L}^{2}\right)$ in the equatorial plane are: $\mathrm{Fe}(1)-\mathrm{O}(1) 2.033(2) / 2.087(3)$ $\AA, \mathrm{Fe}(1)-\mathrm{O}(2) 2.029(2) / 2.043(3) \AA, \mathrm{Fe}(1)-\mathrm{N}(3) 2.194(3) / 2.176(3) \AA ⿻, \mathrm{Fe}(1)-\mathrm{N}(4) 2.188(3) / 2.203(3) \AA ⿻ \mathrm{Fe}(1)-\mathrm{N}(5)$ $2.194(3) / 2.187(3) \AA$, while metal - apical atoms distances are - Fe(1)-O(1W) 2.036(2)/2.035(3) $\AA, \mathrm{Fe}(1)-\mathrm{O}(2 \mathrm{~W})$ 
$2.035(2) / 2.028(3) \AA$ (Table 2). The obtained values of the interatomic distances do not differ from those found in the complex diaqua-(2',2"'-(2,6-pyridinediyldiethylidyne)dioxamohydrazide)-iron(III) perchlorate hydrate [27,28]. In the Cambridge Structural Database 47 hits on structures of compounds of transition metals with ligands of this class are reported [29], mainly manganese or cobalt compounds, only 6 of them being iron compounds [27-33].

The analysis of the geometry of the ligands $\mathrm{H}_{2} \mathrm{~L}^{1} / \mathrm{H}_{2} \mathrm{~L}^{2}$ in III and IV shows that they are flat and four articulated pentametallocycles are formed as a result of their coordination to the metal in the equatorial plane. Two of the metallocycles are formed by the atoms OCNNFe, and two- by NCCNFe. Herewith, the values of dihedral angles between the formed metallocycles are in the range $1.1-5.7^{\circ}$ in III and $0.4-2.2^{\circ}$ in IV. In the same interval are the values of the dihedral angles between the coordinated atoms $\mathrm{N}_{3} \mathrm{O}_{2}$ of the ligand $\mathrm{H}_{2} \mathrm{~L}$ and the planes of the terminal pyridine rings, and between the terminal pyridine rings $\left(2.9,2.0,5.3,3.4^{\circ}\right.$ in III and $2.6,3.0,13.0,13.5^{\circ}$ in IV).

The analysis of positioning the hydrogen atoms from the ligands $\mathrm{H}_{2} \mathrm{~L}^{1} / \mathrm{H}_{2} \mathrm{~L}^{2}$ demonstrated the proton transfer from the $\mathrm{N}(2)$ and $\mathrm{N}(6)$ atom position to the $\mathrm{N}(1)$ and $\mathrm{N}(7)$ atoms. These conclusions are based both on the analysis of Fourier synthesis and geometrical considerations (distances $\mathrm{N} \cdots \mathrm{O}$ ).

In the crystal of compound III the complex cation $\left[\mathrm{Fe}\left(\mathrm{H}_{2} \mathrm{~L}^{1}\right)\left(\mathrm{H}_{2} \mathrm{O}\right)_{2}\right]^{3+}$ is bound to anions $\left(\mathrm{NO}_{3}^{-}\right)$through the hydrogen bonds $\mathrm{N}(7)-\mathrm{H} \cdots \mathrm{O}(1 \mathrm{~A}), \mathrm{O}(1 \mathrm{~W})-\mathrm{H} \cdots \mathrm{O}(6 \mathrm{~A})$ and $\mathrm{N}(7)-\mathrm{H} \cdots \mathrm{O}(1 \mathrm{~A}), \mathrm{O}(1 \mathrm{~W})-\mathrm{H} \cdots \mathrm{O}(6 \mathrm{~A})$ (Figure 3, Table 3). The molecules of the water of crystallization involved in hydrogen bonds both as the donor and the acceptor, contribute to the formation of a complex system of bonds that connect the components in the crystal. The 3D network from the crystal is also determined by the participation of $\mathrm{O}$ atoms from the inorganic $\mathrm{NO}_{3}^{-}$anions to the formation of hydrogen bonds as the acceptor.

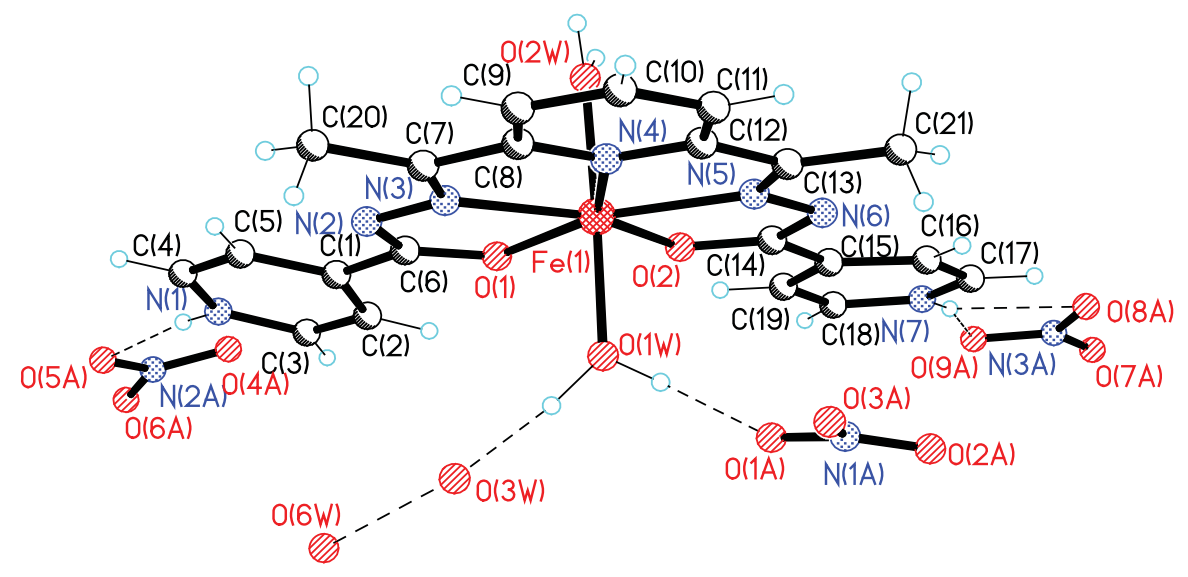

Figure 2. View of formula unit of IV with numbering scheme.

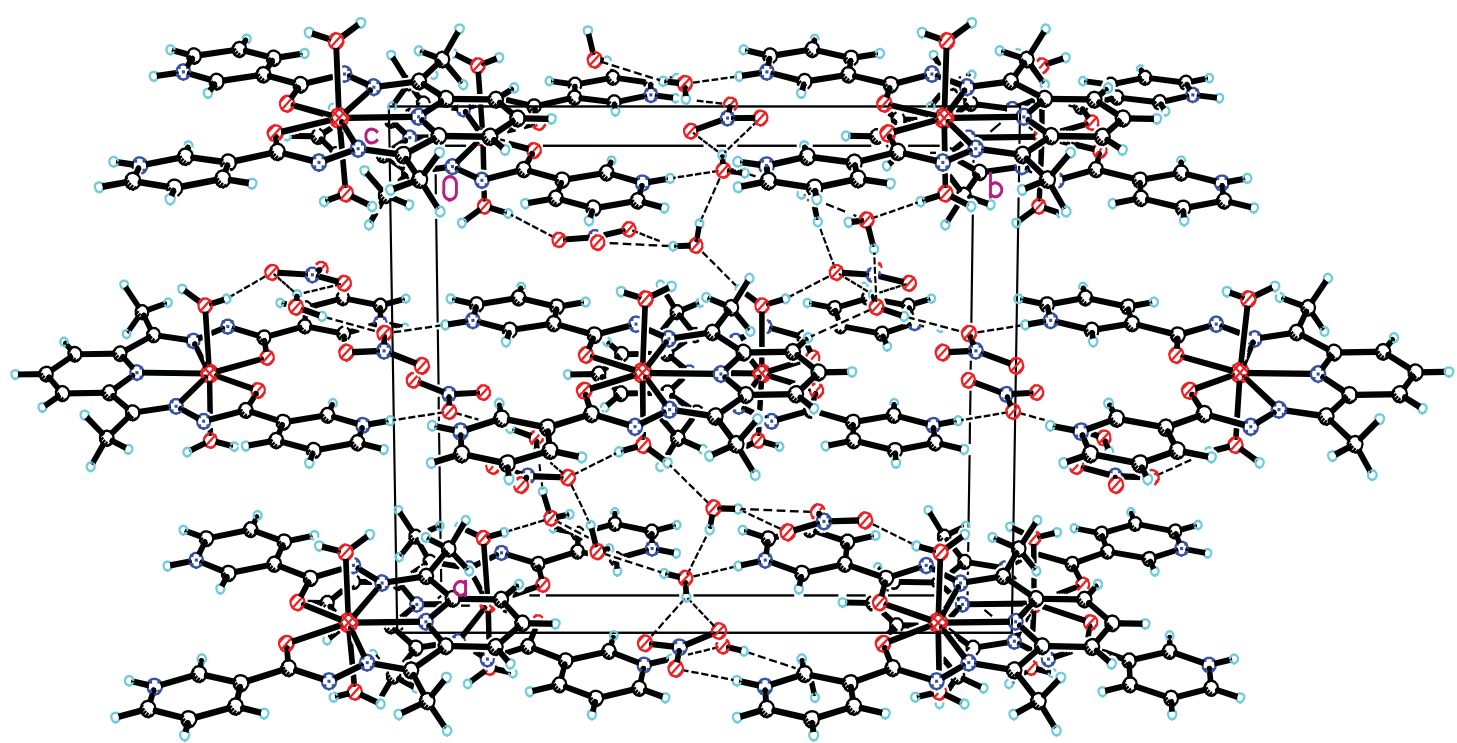

Figure 3. A fragment of crystal packing in III. 
In the crystal of $\mathbf{I V}$ the complex cation $\left[\mathrm{Fe}\left(\mathrm{H}_{2} \mathrm{~L}^{2}\right)\left(\mathrm{H}_{2} \mathrm{O}\right)_{2}\right]^{3+}$ is connected to the anion $\left(\mathrm{NO}_{3}^{-}\right)$through the hydrogen bonds $\mathrm{N}(1)-\mathrm{H} \cdots \mathrm{O}(5 \mathrm{~A}), \mathrm{N}(7)-\mathrm{H} \cdots \mathrm{O}(8 \mathrm{~A}), \mathrm{N}(7)-\mathrm{H} \cdots \mathrm{O}(9 \mathrm{~A}), \mathrm{O}(1 \mathrm{~W})-\mathrm{H} \cdots \mathrm{O}(1 \mathrm{~A}), \mathrm{O}(2 \mathrm{~W})-\mathrm{H} \cdots \mathrm{O}(2 \mathrm{~A}) *$ and $\mathrm{O}(2 \mathrm{~W})-$ $\mathrm{H} \cdots \mathrm{O}(3 \mathrm{~A}) *$ (Figure 4, Table 3$)$. In addition, the complex cations are bound to each other through the hydrogen bonds of the type $\mathrm{O}(2 \mathrm{~W})-\mathrm{H} \cdots \mathrm{O}(2)^{*}$. The molecules of the water of crystallization involved in hydrogen bonds both as the donor and the acceptor, contribute to the formation of a complex system of bonds that connect the components in the crystal. The $3 \mathrm{D}$ network from the crystal is also determined by the participation of $\mathrm{O}$ atoms from the inorganic $\mathrm{NO}_{3}^{-}$anions to the formation of hydrogen bonds as the acceptor. In the crystal, centrosymmetric clusters of four molecules of water of crystallization and two $\mathrm{NO}_{3}^{-}$anions $(\mathrm{N}(3 \mathrm{~A}), \mathrm{O}(3 \mathrm{~W})$ and $\mathrm{O}(6 \mathrm{~W}))$ can be seen.

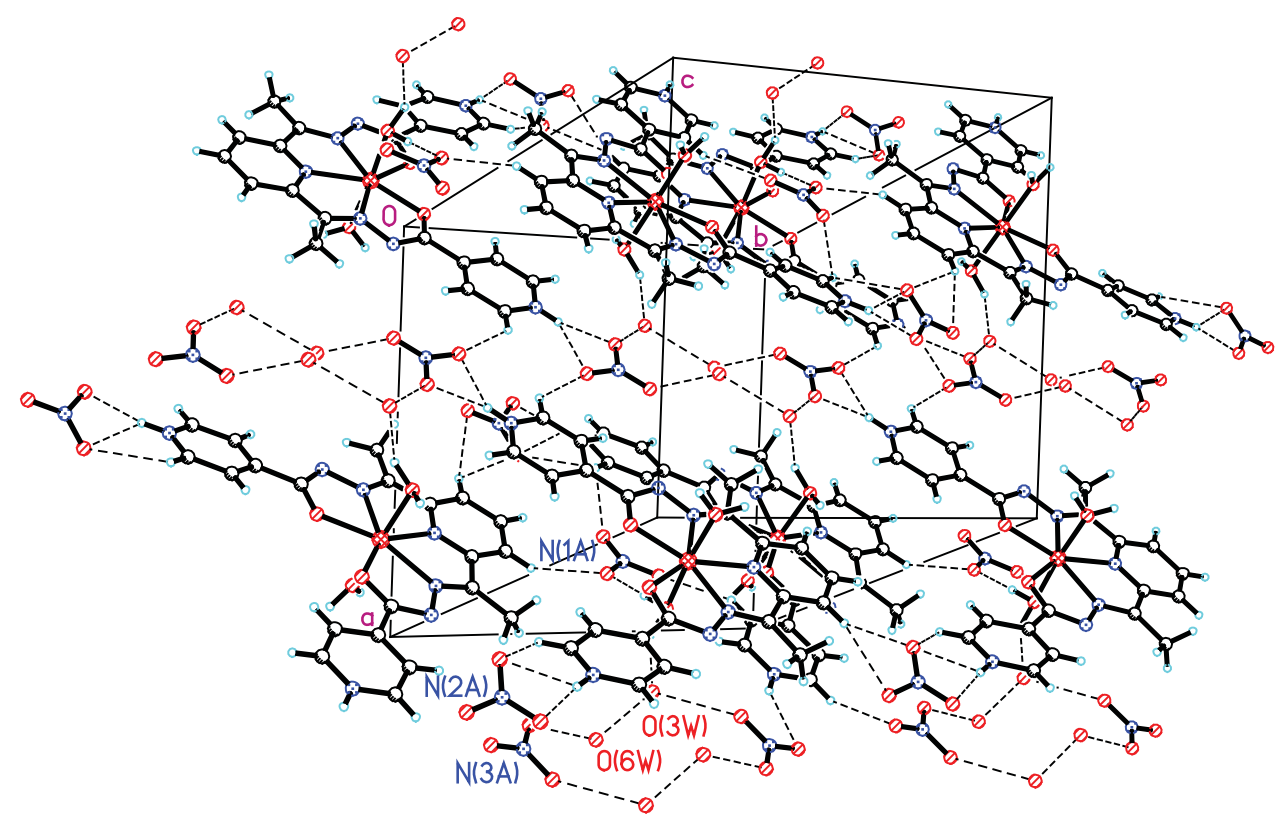

Figure 4. A fragment of crystal packing in IV.

\section{Microbiology}

The influence of iron(III) coordination compounds with nitrogen-containing ligands on the enzyme activity of Aspergillus niger CNMN FD 10 micromycete is presented in Table 4. Each type of enzyme reacted differently to the addition of the coordination compounds into the nutrient medium.

Cellobiohydrolase is an enzyme acting on the key stages of the hydrolysis of cellulose and releasing cellobiose from the non-reducing ends of the chains. In the control samples, without complexes, on the $6^{\text {th }}$ day of cultivation of the producer, the activity of the enzyme was $0.14 \mathrm{U} / \mathrm{mL}$. The maximal activity of cellobiohydrolase was observed on the $7^{\text {th }}$ day of cultivation, constituting $0.18 \mathrm{U} / \mathrm{mL}$. Coordination complexes have demonstrated an obvious inhibitory effect on the biosynthesis of cellobiohydrolase. Particularly, the inhibition increased with the raise of the concentration of compounds from $5 \mathrm{mg} / \mathrm{L}$ to $15 \mathrm{mg} / \mathrm{L}$. Thus, on the day with the maximum biosynthesis of cellobiohydrolase (the $7^{\text {th }}$ day), using compounds II, III and IV at the concentration of $5 \mathrm{mg} / \mathrm{L}$, the enzyme activity in experimental samples constituted $0.16-0.17 \mathrm{U} / \mathrm{mL}$, which was $5.88-12.5 \%$ lower than in the control samples $(0.18 \mathrm{U} / \mathrm{mL})$. With the augment of the concentration to $15 \mathrm{mg} / \mathrm{L}$ the activity of cellobiohydrolase decreased to $0.11-0.12 \mathrm{U} / \mathrm{mL}$, i.e. it was $39-40 \%$ lower, as compared to the control. Compound I showed the greatest inhibitory effect, reducing the enzyme activity to zero in the concentration of $15 \mathrm{mg} / \mathrm{L}$. On the next days $\left(8^{\text {th }}\right.$ and $\left.9^{\text {th }}\right)$ the inhibitory effect was maintained.

$\beta$-Glucosidase is an enzyme acting at the final stages of cellulose hydrolysis, which cleaves cellobiose (formed after the action of cellobiohydrolase) to glucose. This enzyme reacted less to the addition of coordination compounds in the growth medium, in comparison with cellobiohydrolase.

In the control samples the activity of $\beta$-glucosidase on the $6^{\text {th }}$ day of cultivation was $2.47 \mathrm{U} / \mathrm{mL}$. The maximal activity of $\beta$-glucosidase was observed on the $7^{\text {th }}$ day, being $2.80 \mathrm{U} / \mathrm{mL}$. On the $8^{\text {th }}$ day the enzyme activity decreased insignificantly till $2.59 \mathrm{U} / \mathrm{mL}$. On the $9^{\text {th }}$ day a sharp decrease in activity of $\beta$-glucosidase to $1.69 \mathrm{U} / \mathrm{mL}$ was observed. 


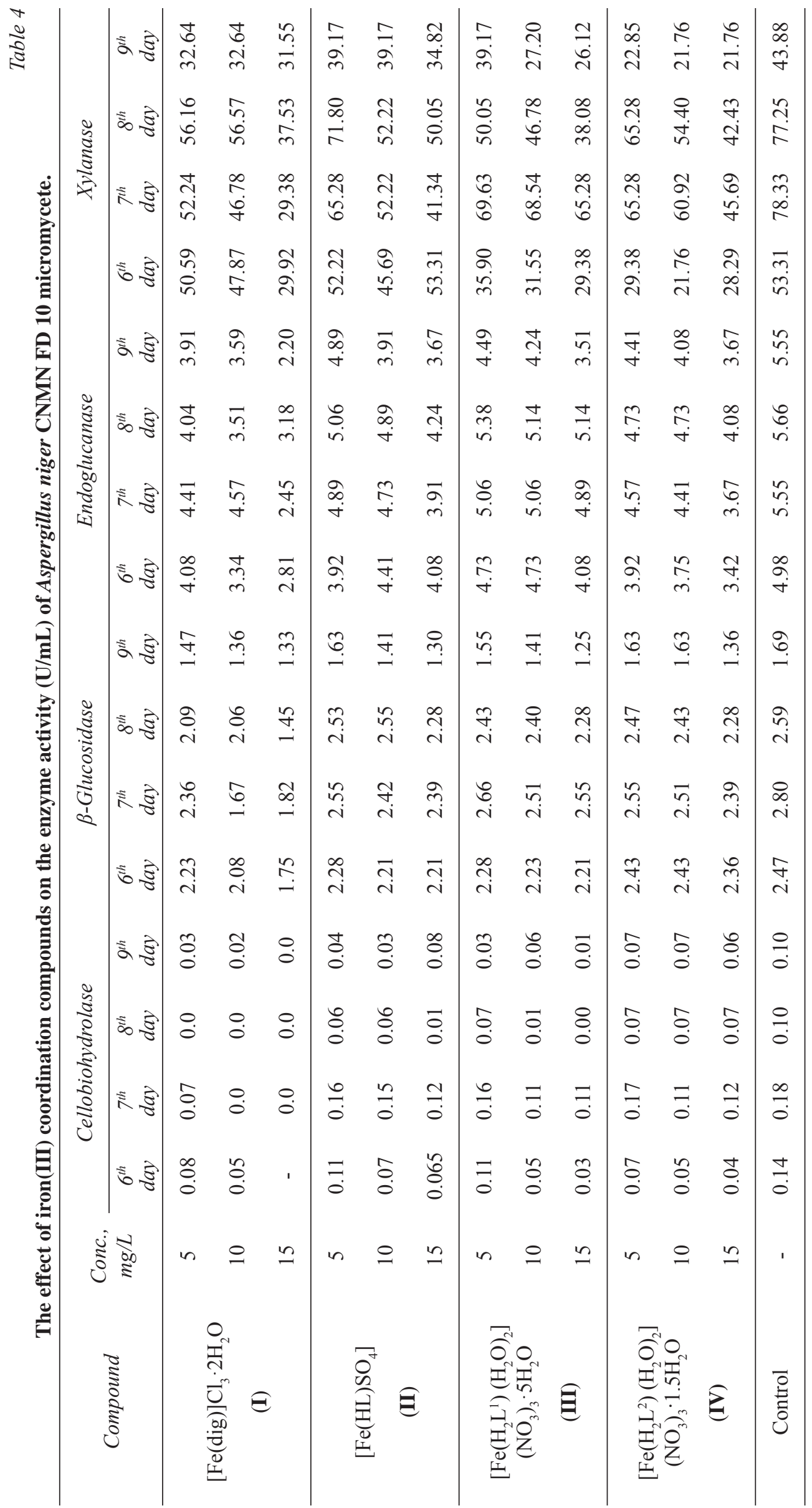


The use of coordination compounds at the lowest concentration $(5 \mathrm{mg} / \mathrm{L})$ showed the $\beta$-glucosidase activity of $2.23-2.43 \mathrm{U} / \mathrm{mL}$ (on the $6^{\text {th }}$ day), $2.36-2.66 \mathrm{U} / \mathrm{mL}$ (on the $7^{\text {th }}$ day), $2.09-2.53 \mathrm{U} / \mathrm{mL}$ (on the $8^{\text {th }}$ day) and $1.47-$ $1.63 \mathrm{U} / \mathrm{mL}$ (on the $9^{\text {th }}$ day). Comparison with the control samples revealed that the inhibitory effect was not significant. With the elevation of the concentration of compounds to $15 \mathrm{mg} / \mathrm{L}$, the activity of $\beta$-glucosidase decreased more, however, the enzyme activity of compounds II, III and IV did not exceed $20 \%$. The greatest inhibitory effect both on the biosynthesis of $\beta$-glucosidase and cellobiohydrolase was shown by the iron complex $\mathbf{I}$, containing chloride ions and dig-ligand. At the concentration of $15 \mathrm{mg} / \mathrm{L}$ the activity of $\beta$-glucosidase constituted: $1.75 \mathrm{U} / \mathrm{mL}$ (control $-2.47 \mathrm{U} / \mathrm{mL}$ ) - on the $6^{\text {th }}$ day, $1.82 \mathrm{U} / \mathrm{mL}$ (control $-2.80 \mathrm{U} / \mathrm{mL}$ ) - on the $7^{\text {th }}$ day; $1.45 \mathrm{U} / \mathrm{mL}$ (control $-2.59 \mathrm{U} / \mathrm{mL}$ ) - on the $8^{\text {th }}$ day, which was $41.14 \% ; 53.85 \%$ and $78.62 \%$ lower than the activity in the control samples, respectively.

Endoglucanases are enzymes that hydrolyze cellodextrins and cellulose derivatives, such as CMC (carboxymethyl cellulose). In the control samples the activity of endoglucanase varied insignificantly- $5.55-5.66 \mathrm{U} / \mathrm{mL}$ on the $7^{\text {th }}-9^{\text {th }}$ days of cultivation with maximal activity on the $8^{\text {th }}$ day. As in the case of cellobiohydrolase and $\beta$-glucosidase, all tested complexes demonstrated an inhibitory effect, which enhanced with the increase of the concentration of compounds, regardless of the culture period. Thus, in the day of the maximal activity of the endoglucanase (the $8^{\text {th }}$ day) it decreased depending on the complex and the applied concentration (from $5 \mathrm{mg} / \mathrm{L}$ to $15 \mathrm{mg} / \mathrm{L}$ ) from $5.38 \mathrm{U} / \mathrm{mL}$ to $3.18 \mathrm{U} / \mathrm{mL}$. The lowest inhibitory effect was noted in the presence of compound III: the enzyme activity decreased from $5.38 \mathrm{U} / \mathrm{mL}$ to $5.14 \mathrm{U} / \mathrm{mL}$. The highest inhibitory effect was registered in the presence of compound $\mathbf{I}$ : the enzyme activity dropped from $4.04 \mathrm{U} / \mathrm{mL}$ to $3.18 \mathrm{U} / \mathrm{mL}$.

Similar results were obtained for xylanase, enzyme that decomposes hemicellulose, one of the major components of plant cell walls. In the control samples the maximal activity of the xylanase was on the $7^{\text {th }}$ and $8^{\text {th }}$ days, constituting $78.33 \mathrm{U} / \mathrm{mL}$ and $77.25 \mathrm{U} / \mathrm{mL}$, respectively. On the $9^{\text {th }}$ day xylanase activity decreased to $43.88 \mathrm{U} / \mathrm{mL}$. Similarly to the afore-discussed enzymes, the inhibitory effect of all studied coordination compounds raised with the increase of the concentration, regardless of the culture period. For example, on the $7^{\text {th }}$ day of cultivation, xylanase activity decreased, depending on the composition of the complex and the concentration (from $5 \mathrm{mg} / \mathrm{L}$ to $15 \mathrm{mg} / \mathrm{L}$ ) from $69.63 \mathrm{U} / \mathrm{mL}$ to $41.34 \mathrm{U} / \mathrm{mL}$, as compared to the activity of xylanase in the control samples of $78.33 \mathrm{U} / \mathrm{mL}$. As in the case of the endoglucanase, the weakest inhibitory effect was shown by complex III and the greatest- at the use of complex I.

The properties of the investigated iron(III) coordination compounds with different ligands (especially, complex I) to inhibit the biosynthesis of cellulases and xylanase at Aspergillus niger CNMN FD 10 micromycete suggests the possibility of their use in plant protection, namely in the diseases caused by microscopic fungi of the genus Aspergillus.

\section{Conclusions}

Iron(III) complexes with Schiff bases with 2,6-diacetylpyridine-bis(nicotinoylhydrazone) and 2,6-diacetylpyridine-bis(isonicotinoylhydrazone) and complexes with semicarbazide diacetic acid dihydrazide and sulfadiazine, have demonstrated biologic activity. The Schiff bases coordinate to iron(III) as pentadentate ligands, forming coordination compounds with pentagonal bipyramidal molecular structure, their base being composed of neutral molecule of the Schiff base that are coordinated via the set of the $\mathrm{N}_{3} \mathrm{O}_{2}$ donor atoms, and the water molecules localized on its peaks.

All tested Fe(III) complexes with nitrogen-containing ligands, caused an inhibitory effect on the biosynthesis of hydrolases at Aspergillus niger CNMN FD 10, which increased with the raise of concentration.

Coordination compounds showed different effects on the biosynthesis of the enzymes synthesized by Aspergillus niger CNMN FD 10 micromycete, due to the different specificity of action of these hydrolases: complexes largely inhibited cellobiohydrolase and less - $\beta$-glucosidase. The inhibitory effect on the endoglucanase and xylanase was approximately the same.

The greatest inhibitory effect was demonstrated by $[\mathrm{Fe}(\operatorname{dig})] \mathrm{Cl}_{3} \cdot 2 \mathrm{H}_{2} \mathrm{O}(\mathbf{I})$, containing chloride ion and semicarbazide diacetic acid dihydrazide, the lowest inhibitory effect was shown by $\left[\mathrm{Fe}\left(\mathrm{H}_{2} \mathrm{~L}^{1}\right)\left(\mathrm{H}_{2} \mathrm{O}\right)_{2}\right]\left(\mathrm{NO}_{3}\right)_{3} \cdot 5 \mathrm{H}_{2} \mathrm{O}(\mathbf{I I I})$, containing the Schiff base 2,6-diacetylpyridine bis(nicotinoylhydrazone) and $\mathrm{NO}_{3}{ }^{-}$anions.

\section{References}

1. Ciloci, A.; Bivol, C.; Stratan, M.; Reva, V., Clapco, S.; Tiurin, J.; Rija, A.; Coropceanu, E. The effect of $\left[\mathrm{Co}(\mathrm{DH})_{2}(\mathrm{An})_{2}\right]_{2}\left[\mathrm{TiF}_{6}\right] \cdot 3 \mathrm{H}_{2} \mathrm{O}$ coordination compound on polypeptide spectrum of amylolytic preparation from Aspergillus niger 33-19 CNMN FD 02a strain. The Annals of Oradea University, Biology Fascicle, 2012, 19(2), pp. 128-132.

2. Clapco, S.; Bivol, C.; Ciloci, A.; Stratan, M.; Coropceanu, E.; Tiurin, J.; Rija, A.; Labliuc, S.; Bulhac, I. The effect of some metal complexes of oxime ligands on proteolytic activity of Fusarium gibbosum CNMN FD 12 strain. The Annals of Oradea University, Biology Fascicle, 2013, 20(1), pp. 53-58. 
3. Deseatnic-Ciloci, A.; Tiurina, J.; Ciapurina, L.; Turta, C.; Bivol, C.; Clapco, S.; Dvornina, E.; Labliuc, S. Coordination compounds of copper with aminoacids as potential stimulators of micromycetes extracellular hydrolases biosynthesis. Priorities of Chemistry for a Sustainable Development, PRIOCHEM, Bucharest, Romania, 2013, pp. 119-121.

4. Bourosh, P.; Coropceanu, E.; Ciloci, A.; Clapco, S.; Bologa, O.; Bivol, C.; Tiurina, J.; Bulhac, I. New Co(III) dioximates with hexafluorophosphate ion as stimulators of the proteolytic activity of the micromycete Fusarium gibbosum CNMN FD 12. Russian Journal of Coordination Chemistry, 2013, 39(11), pp. 777-786.

5. Coropceanu, E.; Deseatnic, A.; Stratan, M.; Rija, A.; Bologa, O.; Tiurin, J.; Labliuc, S.; Clapco, S.; Bulhac, I. The study of the biological activity of some cobalt(III) dioximates with fluorine containing anions. Chemistry Journal of Moldova, 2008, 3(2), pp. 70-80.

6. Dulcevscaia, G.; Kravtsov, V.; Macaev, F.; Duca, Gh.; Stingachi, E.; Pogrebnoi, S.; Boldescu, V.; Clapco, S.; Tiurina, J.; Deseatnic-Ciloci, A.; Lipkowski, J.; Liu, S.-X.; Decurtins, S.; Baca, S. New copper(II) complexes with isoconazole: synthesis, structures and biological properties. Polyhedron, 2013, 52, pp. 106-114.

7. Bivol, C.; Lazarescu, A.; Turta, C.; Rudic, V. Action of some coordinative compounds of Fe(III) with $\alpha$-aminoacids on photosynthetical pigments content in microalgae Dunaliella salina CVNMN-AV-01. Journal of Academy of Sciences of Moldova. Life sciences, 2012, 3(317), pp. 149-154. (in Romanian).

8. Rudic, V.; Cepoi, L.; Rudi, L.; Miscu, V.; Chiriac, T.; Cojocari, A.; Lozan, V.; Coropceanu, E.; Bologa, O. Influence of coordinative compounds of cobalt with dioximates on biosynthetical processes in red alga Porphiridium cruentum. Journal of Academy of Sciences of Moldova. Life sciences, 2012, 1(316). pp. 144-151. (in Romanian).

9. Rudi, L.; Cepoi, L.; Miscu, V.; Chiriac, T.; Valuta A.; Codreanu, S.; Sadovnic, D.; Rudic, V. Biomass and carotenoid production by green alga Haematococcus pluvialis during the life cycle under the influence of Co(II) Schiff base complexes. Journal of Academy of Sciences of Moldova. Life sciences, 2014, 2(323), pp. 163-171. (in Romanian).

10. Valuta, A.; Cepoi, L.; Rudi, L.; Bulhac, I.; Bourosh, P.; Bologa, O. Phycobiliprotein accumulation in cyanobacterium Nostoc linckia and modification of antioxidant activity. The Annals of Oradea University, Biology Fascicle, 2015, 22(1), pp. 13-19.

11. Ciobanica, O.; Bourosh, P.; Bologa, O.; Bulhac, I.; Lozan, V.; Shofransky, V. Synthesis and crystal structure of a new Fe(ii) $\alpha$-dioximate with triazine. Chemistry Journal of Moldova, 2013, 8(1), pp. 78-82.

12. Usatii, A.; Topala, L.; Chirita, E. Calcatiniuc, A., Borisova, T. Productivity, lipidogenesis and carotinogensis of yeast Rhodotorula gracilis CNM-YS-III/20 at the cultivation in presence of coordinative compounds of $\mathrm{Mo}(\mathrm{IY}), \mathrm{Cr}(\mathrm{III})$, Co(III), V(V). Journal of Academy of Sciences of Moldova. Life sciences, 2003, 1, pp. 99-103. (in Romanian).

13. Vomisescu, C.; Bourosh, P.; Kravtsov, V.; Dragancea, D. Nickel(II) complex derived from 2-hydroxy-3methoxybenzaldehyde semicarbazone and 2,2'-bipyridine. Chemistry Journal of Moldova, 2013, 8(2), pp. 78-82.

14. Ciloci, A.; Tiurina, J.; Bologa, O.; Clapco, S.; Labliuc, S.; Pasha, L.; Coropceanu, E.; Rija, A. Coordinative compounds of Mo and $\mathrm{V}$ as possible stimulators of biosynthesis of exocellular cellulases of micromycete Penicillium expansum CNMN FD 05 C. Journal of Academy of Sciences of Moldova. Life sciences, 2012, 3(318), pp. $158-165$. (in Russian).

15. Lemenovschi, D.A. Metalic composition in nature. Soros Educational Journal, 1997, 9, pp. 48-54. (in Russian).

16. Ershov, Iu.A.; Pletneova, T.V. The chemistry of biogenic elements. Vysshaja shkola: Moscow, 1993,560 p. (in Russian).

17. Verejan, A.V. Coordination compounds of transition metals with semicarbazide diacetic acid and its derivatives. Ph.D. Thesis, A.V. Bogatskii Physico-Chemical Institute, Ukrainian Academy of Sciences, Odessa, Ukraine, 1991. (in Russian).

18. Gerbeleu, N.V.; Verejan, A.V.; Byrca, M.C.; Turta, C.I.; Lozan, V.I.; Bologa, O.A. Mössbauer spectra of coordination compounds of iron(III) with semicarbazide diacetic acid and its dihydrazide. Proceedings of the VI ${ }^{\text {th }}$ Conference on Spectroscopy of Coordination Compounds, Krasnodar, Russia, 1990, p. 170. (in Russian).

19. Sheldrick, G.M. A short history of SHELX. Acta Crystallographica, 2008, A64 (1), pp. 112-122.

20. Ciloci, A.; Tiurina, J.; Clapco, S.; Labliuc, S.; Stratan, M.; Grumeza, M. Fungal strain Aspergillus niger - producer of cellulozolytic and xylanolytic enzymes. MD Patent, 2010, No. 4072. (in Romanian).

21. Haritonov, Iu.Y.; Machoshvili, R.I.; Gogorishvili, P.V.; Shamilishvili, O.H. Investigation of metal coordinative complexes with oxalyl dihydrazide by IR spectroscopy. Russian Journal of Inorganic Chemistry, 1972, 17(11), pp. 2992-2995. (in Russian).

22. Haritonov, Iu.Y.; Machoshvili, R.I.; Goeva, L.V.; Scelokov, R.N. Metal coordinative compounds with diformyl hydrazine. Russian Journal of Coordinative Chemistry, 1975, 1(3), pp. 333-341. (in Russian).

23. Nakamoto, K. IR spectra and Raman spectra of inorganic and organic coordinative compounds. Mir: Moscow, 1991, 536 p. (in Russian).

24. Nakanisi, K. Infrared spectra and structure of organic compounds. Mir: Moscow, 1965, 216 p. (in Russian).

25. Bellami, L. Infrared spectra of complex molecules. IL: Moscow, 1963, 590 p. (in Russian). 
26. Tarasevici, B.N. Infrared spectra of basic class of organic compounds. Reference materials. Moscow, 2012,54 p. (in Russian).

27. Andjelkovic, K.; Bacchi, A.; Pelizzi, G.; Jeremic, D.; Ivanovic-Burmazovic, I. Diaqua-(2',2"' -(2,6pyridinediyldiethylidyne)dioxamohydrazide)-iron(III) perchlorate hydrate WUTPIK. Journal of Coordination Chemistry, 2002, 55, pp. 1385-1392.

28. Palenik, G.J.; Wester, D.W.; Rychlewska, U.; Palenik, R.C. Pentagonal-Bipyramidal Complexes. Synthesis and crystal structures of Diaqua[2,6-diacetylpyridine bis(semicarbazone)]chromium(III) hydroxide dinitrate hydrate and Dichloro[2,6-diacetilpyridine bis(semicarbazone)]iron(III) chloride dehydrate. Inorganic Chemistry, 1976, 15(8), pp. 1814-1819.

29. Allen, F.H. Cambridge structural database. Acta Crystallographica, 2002, 58B(3-1), pp. 380-388.

30. Palenik, G.J.; Wester, D.W. Pentagonal-Bipyramidal complexes. Crystal and molecular structures of chloroaqua(2,6diacetylpyridine bis(semicarbazone))manganese(II),-iron(II),-cobalt(II), and -zinc(II) chloride dehydrates. Inorganic Chemistry, 1978, 17(4), pp. 864-870.

31. Bonardi, A.; Carini, C.; Merlo, C.; Pelizzi, C.; Pelizzi, G.; Tarasconi, P.; Vitali, F.; Cavatorta F. Synthesis, spectroscopic and structural characterization of mono- and bi-nuclear iron(II) complexes with 2,6-diacetylpyridine bis(acylhydrazones). Journal of the Chemical Society. Dalton Transactions, 1990, pp. 2771-2777.

32. Gao-Feng, Liu; Filipovic, M.; Heinemann, F.W.; Ivanovic-Burmazovic, I. Diaqua-(2,6-diacetylpyridinebis(semiox amazide)-N,N',N",O,O')-iron(II) dinitrate monohydrate TIRFAC. Inorganic Chemistry, 2007, 46, pp. 8825-8835.

33. Bar, A.K.; Pichon, C.; Gogoi, N.; Duhayon, C.; Ramasesha, S.; Sutter J. Single-ion magnet behavior of heptacoordinated $\mathrm{Fe}(\mathrm{II})$ complexes: on the importance of supramolecular organization. Chemical Communications, 2015, 51(17), pp. 3616-3619. 